UDC 344.65

LBC 67.410 .2

\title{
THE EFFICIENCY OF USING THE CRIMINAL PROCEDURAL INSTITUTIONS IN THE CRIMINAL LAW POLICY OF RUSSIA IN THE FIELD OF NATIONAL SECURITY (THE PROBLEM STATEMENT)
}

\author{
Stanislav N. Kabelkov \\ Volgograd State University, Volgograd, Russian Federation
}

Introduction: the statement of the fact of the threats existence in ensuringthe national security obliges the state to create a mechanism to eliminate them in the present and prevent their occurrence in the future. The criminal law policy of the state is one of the parts of this mechanism. While recognizing its effectiveness, the consideration should be given to the creation of the legal instruments that would make it more successful. In this regard, the author set a goal to determine the current state of implementing the rules of criminal procedure law in the field of the national security for their further effective use in the field of criminal law policy of the Russian state. Methods: the methodological framework for the research is the methods of scientific cognition, among which the main are the methods of analysis, analogy, the study of investigative and judicial practice, legal modeling, etc. Results: the author's standpoint stated in the paper is based on the existing criminal procedure legislation and the investigative and judicial practice. Conclusions: the current state of criminal procedure law contributes to implementing the criminal policy of the Russian state. However, increasing the efficiency of its use requires further development in certain areas. Among them are theoretical, methodological, legislative and other areas.

Key words: national security, criminal law policy of Russia, criminal process, institutions of criminal procedure law, coercive measures, preventive measures.

УДК 344.65

ББК 67.410 .2

\section{ЭФФЕКТИВНОСТЬ ИСПОЛЬЗОВАНИЯ УГОЛОВНО-ПРОЦЕССУАЛЬНЫХ ИНСТИТУТОВ В УГОЛОВНО-ПРАВОВОЙ ПОЛИТИКЕ РОССИИ В ОБЛАСТИ ОБЕСПЕЧЕНИЯ НАЦИОНАЛЬНОЙ БЕЗОПАСНОСТИ (ПОСТАНОВКА ПРОБЛЕМЫ)}

\author{
Станислав Николаевич Кабельков \\ Волгоградский государственный университет, г. Волгоград, Российская Федерация
}

\footnotetext{
Введение: констатация факта существования угроз в сфере обеспечения национальной безопасности обязывает государство создать механизм, позволяющий устранить их в настоящем и не допустить их возникновения в будущем. В качестве одной из частей данного механизма выступает уголовно-правовая политика государства. С одновременным признанием ее эффективности необходимо задуматься о создании правового инструментария, который позволит сделать ее более успешной. В связи с этим автор работы поставил цель определить современное состояние реализации норм уголовно-процессуального права в сфере обеспечения национальной безопасности для дальнейшего эффективного использования их в сфере уголовноправовой политики российского государства. Методы: методологическую основу исследования составляют методы научного познания, среди которых выделяются методы анализа, аналогии, изучения следственносудебной практики, правового моделирования и др. Результаты: изложенная в работе авторская позиция опирается на действующее уголовно-процессуальное законодательство и следственно-судебную практику.
} 
Выводы: современное состояние уголовно-процессуального права способствует реализации уголовной политики российского государства. Однако повышение эффективности ее использования требует дальнейшего развития по отдельным направлениям. Среди них выделяются теоретическое, методическое, законодательное и др.

Ключевые слова: обеспечение национальной безопасности, уголовно-правовая политика России, уголовный процесс, институты уголовно-процессуального права, меры принуждения, меры пресечения.

\section{Введение}

Существование любого государства, позиционирующего себя в качестве самостоятельного и независимого субъекта, предполагает успешную реализацию собственной политики в области обеспечения безопасности. В зависимости от уровня социально-экономических отношений государством определяются приоритетные направления, позволяющие, с одной стороны, обеспечить реализацию своей внешней и внутренней политики, а с другой - гарантировать полноценное использование конституционных прав и свобод своих граждан.

Начальный период становления Российской Федерации как государства сопровождался не только экономическими реформами, но и значительным возрастанием показателей зарегистрированной преступности. Причем количественные изменения преступности сопровождались качественными. Возрастало число проявлений таких особо опасных преступных явлений, как организованная преступность, коррупция, терроризм.

\section{Современное состояние}

российского уголовно-процессуального законодательства в области обеспечения безопасности

Необходимость эффективного противодействия преступности, как явлению, угрожающему национальной безопасности, побудило задуматься о создании действенных механизмов, способных с ним бороться.

Государственная политика в области обеспечения безопасности представляет собой совокупность скоординированных и объединенных единым замыслом мер, в том числе и правовых [7].

Нельзя не заметить, что в рамках реализации стратегии национальной безопасности [6] приняты законы о противодействии эк- стремистской деятельности [11], терроризму [10] и коррупции [9].

Обращает также на себя внимание разработанная Общественной палатой Концепция уголовно-правовой политики России, в которой сформулированы ее цели, задачи и основные направления [3].

Следует признать, что вовлечение в ее реализацию правоохранительных органов дает положительные результаты, которые ежегодно отражаются в статистических сведениях, представляемых Министерством внутренних дел России [4]. Так, в течение последних лет уменьшается количество регистрируемых преступлений. Данная тенденция проявляется и в январе-марте 2018 года. Однако несмотря на снижение числа регистрируемых преступлений увеличилось число преступлений экономической направленности, преступлений, совершенных с целью сбыта наркотических средств, психотропных веществ или их аналогов. В соответствии с п. 3, правовую основу Концепции уголовно-правовой политики России составляют Конституция РФ, общепризнанные принципы и нормы международного права и международные договоры России в области защиты прав человека и контроля над преступностью, Уголовный кодекс РФ и иные федеральные законы, а также нормативные правовые акты Президента и Правительства РФ [3].

В качестве одного из основополагающих источников указан Уголовный кодекс Российской Федерации (далее - УК РФ) [5]. О значении и возможности использования уголовно-процессуальных норм прямо не упоминается. Составители Концепции уголовно-правовой политики России, вероятно, имели их ввиду, указывая на «иные федеральные законы».

Представляется, что некая «невнимательность» связана с тем, что возможности Уголовно-процессуального кодекса Российской Федерации (далее - УПК РФ) [8], в котором закреплены уголовно-процессуальные 
средства, в области обеспечения национальной безопасности недостаточно исследованы, и в связи с этим недооценены, а между тем внимание законодателя к этой проблеме совершенно очевидно.

Реализация уголовно-правовой политики требует ответа на вопросы о возможностях и эффективности уже существующих уголовнопроцессуальных институтов и о создании новых. На отдельные аспекты рассматриваемой проблематики в юридической литературе уже обращалось внимание [9].

Естественно, сразу возникает проблема выбора критерия для оценки. Представляется допустимым исходить из возможности решения задач уголовной политики. Такими являются: контроль над преступностью, охрана правопорядка, совершенствование нормативно-правовой базы противостояния преступности и др.

Прежде всего следует сформулировать перечень проблемных вопросов, подлежащих разрешению. Думается, что требуется провести мониторинг существующего уголовно-процессуального инструментария, чтобы найти положительные и отрицательные стороны и пути повышения эффективности.

В общих чертах вопросы, интересующие теорию и практику, можно сформулировать следующим образом:

- можно ли констатировать факт наличия уголовно-процессуальных средств, применяемых в сфере обеспечения национальной безопасности;

- какова область их применения;

- используются ли они сейчас;

- можно ли их заменить иным правовым инструментарием (существует ли альтернатива);

- имеются ли препятствия для их эффективного применения;

- существует ли возможность повышения эффективности;

- на какие сферы воздействовать наиболее эффективно.

Анализируя возможности УПК РФ по обозначенным выше вопросам, можно констатировать, что его нормы как прямо, так и опосредованно способствуют решению задач в области обеспечения национальной безопасности. Так, согласно закону, принятому в декабре 2008 г., уголовные дела по преступле- ниям террористической направленности не могут рассматриваться судом присяжных. Законодатели внесли в этот перечень следующие статьи УК РФ: 205 (теракт), 206 (захват заложников), 208 (организация и участие в незаконном вооруженном формировании), 212 (массовые беспорядки), 275 (государственная измена), 276 (шпионаж), 278 (насильственный захват или удержание власти), 279 (вооруженный мятеж), 281 (диверсия).

Обращают на себя внимание и последние новеллы УПК РФ, а именно Федеральный закон от 18 апреля 2018 г. № 72-Ф3, который дополнил УПК нормой в виде запрета определенных действий [8].

Касаемо области применения норм УПК РФ, можно однозначно утверждать, что в настоящее время применяется весь спектр уголовно-процессуального законодательства при производстве по уголовным делам, затрагивающим национальную безопасность Российской Федерации. И совершенно естественно, что никакой другой нормативно-правовой акт, кроме УПК, не может предложить альтернативного правового инструментария.

Ответы на три последних вопроса требуют комплексного подхода к обозначенной в них проблематике. В настоящее время в правоприменительной практике сложилась следующая ситуация: среди прочих других совершаются преступления, затрагивающие национальную безопасность, и производство по ним осуществляется согласно УПК РФ. И вроде бы очевидных препятствий, которые могли бы возникнуть по данной категории дел при реализации норм действующего УПК на досудебных и судебных стадиях, не существует. В этой связи весьма правомерно было бы озадачиться разрешением вопроса об эффективности возможностей уголовно-процессуального законодательства.

Ответ на него следует искать в тенденциях, оказывающих влияние на современное уголовно-процессуальное право. Конечно, в первую очередь это касается дифференциации уголовного судопроизводства.

Действующий УПК РФ в ч. 4 закрепил «Особый порядок уголовного судопроизводства», а в разделе 16 - особенности производства по отдельным категориям уголовных дел. Представляется, что, учитывая степень об- 
щественной опасности и влияние данной категории дел на государственные интересы вообще, имеет смысл в отдельной главе детализировать особенности производства по уголовным делам в области обеспечения национальной безопасности. В ней должны реализоваться возможности институтов уголовнопроцессуального права, регламентирующих особенности доказывания, применения мер пресечения и принуждения, подследственности, подсудности, а также другие институты, позволяющие разрешить задачи общей и специальной превенции.

\section{Выводы}

Нормы действующего УПК РФ как прямо, так и опосредованно способствуют решению задач в области обеспечения национальной безопасности. С целью их систематизации имеет смысл дополнить раздел 16 УПК «Особенности производства по отдельным категориям уголовных дел» главой, в которой будут учтены особенности производства на досудебных и судебных стадиях по уголовным делам в области национальной безопасности.

\section{СПИСОК ЛИТЕРАТУРЫ}

1. Зеленский, С. Н. Уголовно-процессуальные меры предупреждения нарушения принципа справедливости при обеспечении экологической безопасности / С. Н. Зеленский, Н. А. Соловьева // Правовая парадигма = Legal Concept. -2017 . - № 4. - C. 149156. -DOI: https://doi.org/10.15688/lc.jvolsu.2017.4.21.

2. Конституция Российской Федерации : (принята всенар. голосованием 12 дек. 1993 г.) (с учетом поправок, внесенных Законами РФ о поправках к Конституции РФ от 30 дек. 2008 г. № 6-ФКЗ, от 30 дек. 2008 г. № 7-ФКЗ, от 05 февр. 2014 г. № 2-ФКЗ, от 21 июля 2014 г. № 11-ФКЗ). - Доступ из справ.-правовой системы «КонсультантПлюс».

3. Концепция уголовно-правовой политики Российской Федерации // Общественная палата Российской Федерации. - Электрон. текстовые дан. - Режим доступа: https://www.oprf.ru/ discussions/newsitem/17889. - Загл. с экрана.

4. Состояние преступности за 2018 год // Официальный сайт Министерства внутренних дел Российской Федерации. - Электрон. текстовые дан. Режим доступа: https://50.мвд.pф/DEJATELNOST/ activity/состояние-преступности-за-2018-год. - Загл. с экрана.

5. Уголовный кодекс Российской Федерации от 13 июня 1996 г. № 63-Ф3 (ред. от 23 апр. 2018 г., с изм. от 25 апр. 2018 г.). - Доступ из справ.-правовой системы «КонсультантПлюс».

6. Указ Президента РФ «О Стратегии национальной безопасности Российской Федерации до 2020 года» от 12 мая 2009 г. № 537 : (в действующей ред.). - Доступ из справ.-правовой системы «КонсультантПлюс».

7. Федеральный закон «О безопасности» от 28 дек. 2010 г. № 390-Ф3 : (в действующей ред.). - Доступ из справ.-правовой системы «КонсультантПлюс».

8. Федеральный закон «О введении в действие Уголовно-процессуального кодекса Российской Федерации〉 от 18 дек. 2001 г. № 174-Ф3 : (в действующей ред.). - Доступ из справ.-правовой системы «КонсультантПлюс».

9. Федеральный закон «О противодействии коррупции» от 25 дек. 2008 г. № 273-Ф3 : (в действующей ред.). - Доступ из справ.-правовой системы «КонсультантПлюс».

10. Федеральный закон «О противодействии терроризму» от 06 марта 2006 г. № 35-Ф3 : (в действующей ред.). - Доступ из справ.-правовой системы «КонсультантПлюс».

11. Федеральный закон «О противодействии экстремистской деятельности» от 25 июля 2002 г. № 114-Ф3 : (в действующей ред.). - Доступ из справ.правовой системы «КонсультантПлюс».

\section{REFERENCES}

1. Zelenskiy S.N., Solovyeva N.A. Ugolovnoprotsessualnye mery preduprezhdeniya narusheniya printsipa spravedlivosti pri obespechenii ekologicheskoy bezopasnosti [Criminal Procedural Measures for Preventing Violation of the EquityPrinciple whileEnsuring Ecological Security]. Pravovaya paradigma $=$ Legal Concept, 2017, no. 4, pp. 149-156.

2. Konstitutsiya Rossiyskoy Federatsii: (prinyata vsenar. golosovaniem 12 dek. 1993 g.) (s uchetom popravok, vnesennykh Zakonami RF o popravkakh $k$ Konstitutsii RF ot 30 dek. 2008 g. № 6-FKZ, ot 30 dek. 2008 g. № 7-FKZ, ot 05 fevr. 2014 g. № 2-FKZ, ot 21 iyulya 2014 g. № 11-FKZ) [The Constitution of the Russian Federation: (Adopted by the All-People Vote on December 12,1993) (Taking into Account the Amendments Introduced by the Russian Laws on Amendments to the Constitution of the Russian Federation of December 30, 2008 No. 6-FCL, of December 30, 2008 No. 7-FCL, of February 5, 2014 No. 2-FCL, of July 21, 2014 No. 11-FCL)]. Access from Reference Legal System KonsultantPlyus. 
3. Kontseptsiya ugolovno-pravovoy politiki Rossiyskoy Federatsii [The Conception of the Criminal and Legal Policy of the Russian Federation]. Obshchestvennaya palata Rossiyskoy Federatsii [Public Chamber of the Russian Federation]. URL: https://www.oprf.ru/discussions/newsitem/17889.

4. Sostoyanie prestupnosti za 2018 god [Crime Rate in 2018]. Ofitsialnyy sayt Ministerstva vnutrennikh del Rossiyskoy Federatsii [The Official Website of the Ministry of Internal Affairs of the Russian Federation]. URL: https://50.mvd.rf/ DEJATELNOST/activity/sostoyanie-prestupnosti-za2018-god.

5. Ugolovnyy kodeks Rossiyskoy Federatsii ot 13 iyunya 1996 g. № 63-FZ (red. ot 23 apr. 2018 g., s izm. ot 25 apr. $2018 \mathrm{~g}$.) [Criminal Code of the Russian Federation of June 13, 1996 No. 63-FL (ed. of April 23, 2018 with amendments of April 25, 2018)]. Access from Reference Legal System KonsultantPlyus.

6. Ukaz Prezidenta $R F \ll O$ Strategii natsionalnoy bezopasnosti Rossiyskoy Federatsii do 2020 goda» ot 12 maya 2009 g. № 537: (v deystvuyushchey red.) [Decree of the President of the Russian Federation 'On the Strategy of the National Security of the Russian Federation until 2020' of May 12, 2009 No. 537: (in the Current Version)]. Access from Reference Legal System KonsultantPlyus.

7. Federalnyy zakon "O bezopasnosti» ot 28 dek. 2010 g. № 390-FZ: (v deystvuyushchey red.)
[Federal Law 'On Security' of December 28, 2010 No. 390-FL: (in the Current Version)]. Access from Reference Legal System KonsultantPlyus.

8. Federalnyy zakon "O vvedenii $v$ deystvie Ugolovno-protsessualnogo kodeksa Rossiyskoy Federatsii» ot 18 dek. 2001 g. № 174-FZ: ( $v$ deystvuyushchey red.) [Federal Law 'On the Enactment of the Code of Criminal Procedure of the Russian Federation' of December 18, 2001 No. 174-FL: (in the Current Version)]. Access from Reference Legal System KonsultantPlyus.

9. Federalnyy zakon "O protivodeystvii korruptsii» ot 25 dek. 2008 g. № 273-FZ: ( $v$ deystvuyushchey red.) [Federal Law 'On Combating Corruption' of December 25, 2008 No. 273-FL: (in the Current Version)]. Access from Reference Legal System KonsultantPlyus.

10. Federalnyy zakon "O protivodeystvii terrorizmu» ot 06 marta 2006 g. № 35-FZ: (v deystvuyushchey red.) [Federal Law 'On Counteracting Terrorism' of March 6, 2006 No. 35-FL: (in the Current Version)]. Access from Reference Legal System KonsultantPlyus.

11. Federalnyy zakon "O protivodeystvii ekstremistskoy deyatelnosti» ot 25 iyulya $2002 \mathrm{~g}$. № 114-FZ: (v deystvuyushchey red.) [Federal Law 'On Counteracting Extremist Activity' of July 25, 2002 No. 114-FL: (in the Current Version)]. Access from Reference Legal System KonsultantPlyus.

\section{Information about the Author}

Stanislav N. Kabelkov, Candidate of Sciences (Jurisprudence), Associate Professor, Department of Criminal Procedure and Criminalistics, Volgograd State University, Prosp. Universitetsky, 100, 400062 Volgograd, Russian Federation, kabelkov_stas@mail.ru.

\section{Информация об авторе}

Станислав Николаевич Кабельков, кандидат юридических наук, доцент кафедры уголовного процесса и криминалистики института права, Волгоградский государственный университет, просп. Университетский, 100, 400062 г. Волгоград, Российская Федерация, kabelkov_stas@mail.ru. 